\title{
Consumer Market for Goods and Services as a Mirror of Social and Economic Transformation: From a Centralized Economy to the Accession of Russia the World Trade Organization
}

\author{
Shabanova L.B. \\ Institute of Economics, Management and Law, Kazan, 420111, Russia
}

Ismagilova G.N.

Kazan Federal University, Kazan, 420008, Russia

Doi:10.5901/mjss.2014.v5n18p247

\begin{abstract}
Abstarct
After having eliminated the disadvantages of centrally planned economy, the reforms being held in Russia have generated negative phenomena and factors that led to the backlog of Russia's economy from its pre-reform counterpart in several ways: by source and economic growth, labor productivity, wage levels, purchasing power and income differentiation, efficiency and quality of public administration, scope of criminalization and corruption in the economy. The relevance of these issues is enhanced due to Russia's WTO accession.
\end{abstract}

Keywords: consumer market for goods and services, centralized economy, socio-economic transformation, economic and financial crisis.

Reforming and development of the sphere of the consumer market for goods and services is one of the most important areas of socio-economic transformation in Russia, which began in the early 90 -ies of the last century.

Despite the fact that under the centrally planned economy the consumer market for goods and services industry was a branch of commodity-money circulation regulated by the government, in fact it was characterized by lack of balance. Growth in production of consumer goods lagged behind the growth of cash income; a process of the growth of unsatisfied demand of the population was going on as well as the shortage of goods, queues, and speculation. This is evidenced by the ratio between the major economic indicators of the consumer market for the last pre-reform year. (Table1).

Table 1. Basic economic indicators of the consumer market for goods and services in 1990 [1, page 11, 13, 23, 136]

\begin{tabular}{|l|c|}
\hline Index & 1990 г. \\
\hline Production of consumer goods (retail prices), in billion rubles - total & 247 \\
\hline Retail trade turnover in state and cooperative trade (at current prices), in billion rubles & 21,4 \\
\hline Incomes of the population in billion rubles including remuneration (salary and income from & 384,7 \\
collective farms) total & 198,8 \\
\hline
\end{tabular}

The data show that the amount of money income exceeds the production of consumer goods and retail turnover.

Existing economic conditions hindered the development of market relations. This was due to the mono-subjective system of the economy, based on the use of the unified state property; excessive regulation of production and economic processes at the macro level, the restriction of economic freedoms management; orientation of the material and financial support of all economic structures to the centralized methods.

Over the past two decades, Russia has gone through two stages of its development. In the first phase (in 1990s) the country was overcoming a large-scale macroeconomic crisis and creating economic and political institutions, without which modern society cannot function: private property, monetary system, fiscal system of federalism. In the second phase (2000-2003) the process of market economic institutions began: transformation of natural monopolies, development of legislation on insolvency (bankruptcy), tax and land laws, drafting a Federal Law "On goods and services of general economic interest and price formation on them" began and other laws. [2, pages 14-16]. 
Due to the fact that the consumer market for goods and services fulfils the function of meeting the solvent demand, coordination of interests of all participants in the economic process, including the state, the economic reforms in Russia and privatization of economic entities in trade and services began.

In accordance with the adoption on November 25, 1991 the Decree of the President of the Russian Federation "On the commercialization of trading enterprises in the Russian Soviet Federative Socialist Republic" trading companies and service industries and catering were provided with full legal and economic independence by separating them from the government organizations on the right of legal entities; bidding, Departments of Workers' Supply (ORS), trusts and syndicates were abolished.

Thus, conditions for the formation of market relations based on the priority of the interests of businesses and their freedom of entrepreneurial activity were created.

Within a short period of time the centralized and regulated system of distribution of goods was replaced by free purchase and sale system. However, instead of diverse forms of ownership, the leading position in the consumer market for goods and services was taken by the private sector. In 2005, the share of private sector in the Republic of Tatarstan had $98.2 \%$ of retail sales; in 2010 - 99.6\% [3, page 385].

In recent years a steady growth in the volume of goods and services as a whole and per capita in Russia and in the Republic of Tatarstan has emerged. However, due to the deep stratification of the population by income level the indicator of the "turnover of goods and services per capita" does not reflect the real socio-economic phenomena and processes.

Modern consumer market of the country and its regions differs relative saturation of goods and services. Thus, the consumer market of the Republic of Tatarstan is as follows (Table 2) [3, page 385].

Until 2007, the country has seen steady growth in retail turnover. But the global financial and economic crisis has made adjustments, and, since 2007, domestic trade turnover growth has slowed, and in 2009 altogether showed negative results.

Table 2. Indicators of retail trade of the Republic of Tatarstan in 2005-2012 years

\begin{tabular}{|l|c|c|c|c|c|c|c|c|}
\hline Indicator & 2005 & 2006 & 2007 & 2008 & 2009 & 2010 & 2011 & 2012 \\
\hline Retail trade turnover, in billion rubles & 161,4 & 213,9 & 275,1 & 369,3 & 393,9 & 454,4 & 534,9 & 650,7 \\
\hline Growth rate (in percentage to the previous year in comparable prices) & 123,4 & 125,3 & 120,9 & 119,9 & 97,9 & 108,9 & 109,1 & 116,4 \\
\hline Retail trade turnover per capita, in thousand rubles & 42,88 & 56,7 & 73,43 & 98,07 & 104,4 & 120 & 140.9 & 170.6 \\
\hline
\end{tabular}

Only since 2008 has began the declining of share of food products and increase of the share of non-food products in the commodity structure of retail trade. This process is a confirmation of the gradual improvement of living standards and the formation of market trends, products and services for countries with developed market economies (Table 3) [3, page 385].

The main reasons for the reduction of the rate of growth in retail turnover are the decline in industrial production, the reduction of investments in the economy, unemployment growth, decline of incomes of population and business activity of retail units. However, the main factors limiting business activity of trade organizations in the conditions of crisis have become the lack of solvent demand, lack of own funds and a high percentage of commercial loans.

Table 3 and Figure 1 show the commodity structure of retail trade turnover in recent years.

Table 3. Commodity structure of retail trade turnover (in\%)

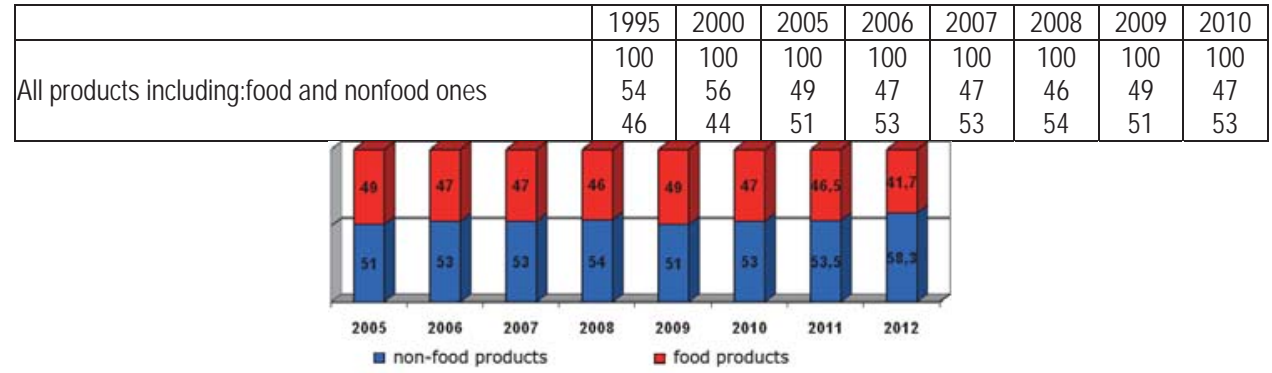

Figure 1. Marketable structure of retail trade turnover (in\%) 
From the above data it is clear that the development of the consumer market for goods and services in the Republic of Tatarstan has been formed and the positive trends continue to strengthen. At first, the density of food products has increased in retail trade turnover. Commodity structure of retail trade turnover shows that in 2009 the proportion of nonfood products decreased quite significantly. This reflects the level of consumer expectations, which was due to lower incomes. However, since 2010 the share of non-food products returned to pre-crisis level and stabilized.

Secondly, the number of residents who prefer to shop at retail markets increased. Pre-crisis tendency was the rapid decrease in the proportion of sales of goods on food, merchandise and mixed markets: while in 2000 the figure was 38.1 per cent, over the last 10 years it has decreased by more than 4 times. However, since 2007 there has been a stabilization of market shares in the turnover, and even a slight increase in this indicator. (See Figure 2)

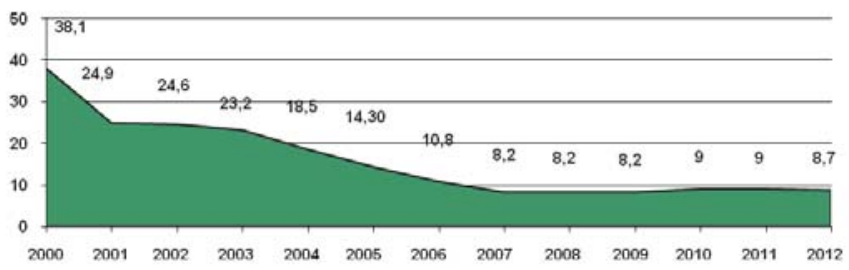

Figure 2. Share of the markets in the retail trade turnover in the Republic of Tatarstan in 2000-2012, (in\%)

Dynamics of retail indicators suggests that, despite the decline in the volume of trade, the retail sector is fairly stable. The Republic of Tatarstan did not stop the introduction of new retail spaces, i.e., economic agents had a better ability to adapt and higher financial capabilities to help overcome the crisis. (see Figure 3)

Today in the Republic of Tatarstan there are about 16,000 retailers and 70 retail markets. Retail establishments of the republic have more than 11 percent of the employed population of Tatarstan, which are about 200 thousand people. In general, the provision of the Republic of Tatarstan with public area shopping facilities per thousand people reached 99, $8 \%$.

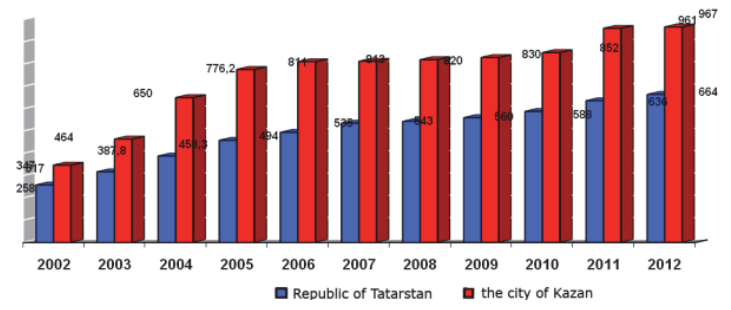

Figure 3. Provision of retail space for 1000 residents in square meters

In terms of turnover of retail trade and catering Tatarstan is among the top ten Russian regions.

In the structure of money income of the population of the Republic of Tatarstan high share of income allocated to the purchase of goods and services remains. (See Figure 4).

Analysis of the statistical data shows that the market for goods and services in the Republic of Tatarstan shows the following positive trends: in the structure of retail trade turnover the share of non-food products exceeds the share of food products, which indicates an increase in demand of the population, there has been a surplus of income over expenditure of the population. The positive dynamics of development of the consumer market of the Republic of Tatarstan is a confirmation of the recognition of the objective laws of the market. 


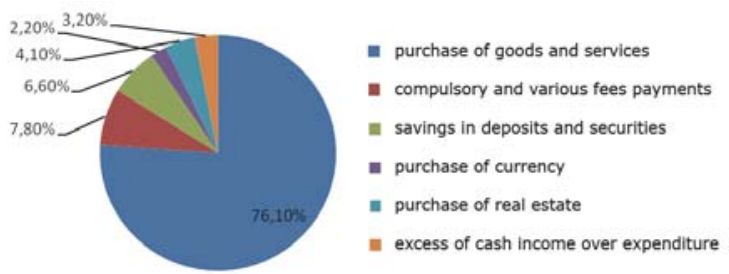

In figure 4: in blue- purchase of goods and services; in red- compulsory and various fees payments; in green- savings in deposits and securities; in purple-purchase of currency; in light blue-purchase of real estate; in yellow- excess of cash income over expenditure

Figure 4. The structure of money income use by the population of the Republic of Tatarstan in 2010

However, the positive trend of development of the consumer market for goods and services is accompanied by a number of negative effects: excessive increase in the proportion of import in the structure of commodity resources exacerbated the problem of quality and food safety compliance; the volume of unorganized food sales, merchandise and mixed markets has increased. Negative trends in the consumer market of the post-reform Russia is a significant increase in the sale of alcoholic beverages, beer and tobacco products, as well as the decline in the share of public catering in total retail turnover .

Thus, the being introduced reforms, on having eliminated the disadvantages of a centrally planned economy, have generated negative effects and constraints in the form of exorbitant taxes, granting freedom of trade and speculative business; expansion of criminal activity (racketeering, extortion, illegal production and economic transactions of state and commercial structures).

The share of imported goods in the structure of retail trade commodity resources has sharply increased. (It rose from $14 \%$ in 1991. to 55\% in 2004, but in 2010 this figure fell to 44\%). Sources filling the market with goods are domestic industrial and agricultural production, as well as import goods. The status of these sources determines the completeness and nature of the proposal. If domestic production does not fully satisfy the demand due to insufficient development or decline, it leads to a shortage of goods or increases the share of imported goods. For the current state of the consumer market the decline of domestic production and increase of the share of imported goods in the structure of the product range is typical.

Extrusion of domestic goods from the domestic goods market by the imported goods is caused by two main reasons. First - it is a relatively low level of competitiveness of Russian goods on the following parameters: quality, packaging, advertising support. Secondly, a great influence has the attractiveness of imports as a source of high-quality goods that remained from the times of socialism and systematic supply of imported goods in the USSR.

However, to date, according to the Office of the Federal Service for Supervision of Consumer Rights Protection and Human Welfare in the Republic of Tatarstan the share of defects in the imported goods ranges between 30 to $80 \%$. Until today, the next trend in export-import relations still exists: Russia exports its best products, and in return gets imported products of dubious quality.

Russia's economy concedes to its pre-reform analogue on a number of directions: by source and economic growth, labor productivity, wage levels, purchasing power and income differentiation, efficiency and quality of public administration, scope of criminalization and corruption in the economy. Liberal reforms have caused the most severe consequences in the social sphere, creating a two-layer economy, which projects real life two dissimilar socio-economic image of Russia.

According to the deputy head of the Accounts Chamber of the Russian Federation V.P. Goregliad about $0.2 \%$ of Russia's population own $70 \%$ of the national wealth; [6] According to the Federal State Statistics Service $12.8 \%$ of the population are in extreme poverty with incomes below 3,500 rubles a month; $15.2 \%$ exist in poverty with incomes of up to 7,000 rubles; $20.2 \%$ fend in poverty with incomes of up to 15,000 rubles; $23.4 \%$ live above the poverty with a monthly income of up to 25,000 rubles; $10.7 \%$ live with average incomes and their incomes make up to the amount of 35,000 rubles. $11.8 \%$ of the population receives over 35,000 rubles; $4.1 \%$ of the population is considered wealthy; they receive up to 75,000 rubles. And only $2.5 \%$ of the population has an income above 75,000 rubles. [5, page 9, 13]. Thus, $71.6 \%$ of the population with varying success balances on the poverty line.

Therefore, currently Russia faces the goal of sustainable economic growth. Pushed to the forefront is the problem 
of flexibility and adaptability of the economic system, forming ability of economic agents, quickly and adequately responding to the changes occurring in the modern economy. [7]

Especially it should be noted that during the reform the role of the consumer market in the economy of the country has increased. According to the Russian system of national accounts, the share of trade and catering industry in sectoral structure in gross value added at current prices rose from $6 \%$ in 1990 to $20.6 \%$ in 2005 and to $12.9 \%$ in 2010 . In addition, during the reforms the number of employees in the consumer goods market increased from $7.8 \%$ in 1990 to $17.2 \%$ in 2004 and to $66.6 \%$ in 2010. In relation to the total average number of employees in the national economy.

All the above indicates that the relevance of this problem is amplified due to Russia's WTO accession. The Ministry of Commerce and Industry (Ministry of Industry) of Russia has developed and approved a sustainable regulatory and legal regulation in the sphere of trade in the Russian Federation for 2011 - 2015 years, and until 2020 on March 31, 2011 (№ 422).

According to this strategy, the retail in its development goes through several stages, each of which has its own characteristics and success factors, characterized by different growth rates, the nature and degree of competition, the quality and range of services provided. For example, the share of modern retail formats in total retail turnover varies widely from country to country. In most developed countries it exceeds $70 \%$.

${ }^{1}$ Modern format of a store is a supermarket, offering a wide assortment of goods and with a space of more than 400 square meters, having one or more stalls of fresh products and offering additional services to customers in its territory (ATM, parking, cafe, toilets, pharmacy items for printing photos etc.). In world practice the following includes the modern formats: hypermarkets, supermarkets, convenience stores, "Cash \& Carry", discounters.
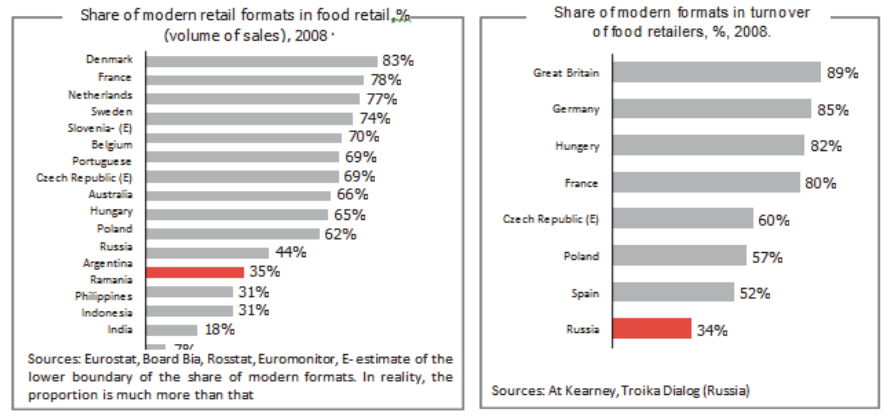

Figure 4. The share of modern retail formats of food and non-food retail turnover

According to the analysis of trade development in the Russian Federation and foreign countries we can identify the main indicators characterizing Russian retailers lag from developed countries.

\begin{tabular}{|l|c|l|l|}
\hline Index & Russia & European Community & Gap, times \\
\hline provision of modern retail space, m2/thousand people & 73 & More than 500 & More than 7 times \\
\hline share of modern formats & 35 & More than 70\% & More than 2 times \\
\hline Share of 5 largest companies (level of consolidation) & $11 \%$ & More than $60 \%$ & 6 and more times \\
\hline Share of remote sales & $1.8 \%$ & More than 5\% & 3 and more times \\
\hline
\end{tabular}

On the example of food trade On the example of Germany, the UK, France, Sweden, Denmark

Figure 5. Key figures of trade in Russia and other countries

- The criteria for effectiveness of the distribution system include:

- Number of modern retail space formats per 1,000 people

It is this criterion that shows the geographical coverage of the distribution system for producers and physical availability of goods to consumers.

- The share of modern formats in turnover of the industry

Modern formats, compared to traditional, differ by more efficient sales (turnover per m2), by lower unit costs, lower prices, higher quality of service and quality control of products. Therefore, this criterion describes the efficiency of the 
distribution system for manufacturers, affordability, quality of goods and services for consumers.

- The degree of consolidation of the industry (the share of the top 5 companies)

Consolidation allows you to implement critically important for the industry effects of scale in procurement, logistics, and mobilization of financial resources.

Only large companies are able to make large-scale investments in innovative technologies and methods of work, i.e., reduce costs and improve the efficiency of the commodity system.

Large companies have the opportunity to influence the supplier to lower prices, improve product quality, increase efficiency of business processes, which will increase the competitiveness of the economy as a whole, i.e., will be an important condition for implementing innovative development of the economy.

This criterion describes the efficiency of the distribution system for manufacturers, affordability, quality of goods and services for consumers, increases the competitiveness of the economy as a whole.

The main objectives of long-term strategy of development of domestic trade are:

- Improvement of regulation of the trade sector

- The development of trade infrastructure

- Promotion of the development of trade in small and remote communities

- Reduction of staffing deficit in trade, improvement of staff

- Provision of conditions for the development of competition

- Support in the development of small and medium businesses

- Encouraging the development of distance selling

- Improvement of traditional retail formats

Addressing these challenges will produce the following target indicators. (see Table 4 and 5)

Table 4. Target Indicators of Strategy

\begin{tabular}{|c|c|c|c|}
\hline Index & 2008 & 2015 & 2020 \\
\hline Provision with modern format areas & 73 & $120-150$ & $200-300$ \\
\hline $\begin{array}{l}\text { The share of modern formats in } \\
\text { turnover, } \%\end{array}$ & $35 \%$ & $45 \%-60 \%$ & $60 \%-80 \%$ \\
\hline $\begin{array}{l}\text { The TOP5 share in turnover } \\
\text { (degree of consolidation), } \%\end{array}$ & $11 \%$ & $25 \%-30 \%$ & $35 \%-50 \%$ \\
\hline Distance trade share, $\%$ & $2 \%$ & $3 \%-4 \%$ & $4 \%-6 \%$ \\
\hline $\begin{array}{l}\text { Turnover of small businesses, } \\
\text { trade, in trillion rubles }\end{array}$ & 7,2 & $9-12$ & $10-13$ \\
\hline The level of competition in trade & $\begin{array}{l}\text { Low } \\
\text { (In most local } \\
\text { markets there is a } \\
\text { single major } \\
\text { player) }\end{array}$ & $\begin{array}{c}\text { Average } \\
\text { (In most cities with a population over } \\
500,000,3 \text { or more larger players are } \\
\text { present }{ }^{*} \text {, there is competition for } \\
\text { smaller settlements) }\end{array}$ & $\begin{array}{c}\text { High } \\
\text { (Almost in all towns with a population } \\
\text { of }>100000 \text { people } 2 \text { or more big } \\
\text { players are present and there is } \\
\text { competition for smaller settlements) }\end{array}$ \\
\hline
\end{tabular}

1 the figure given on the example of food trade. It is assumed that in the other trade segments figures will vary in the same direction

Table 5. Forecast of implementation of the Strategy for innovative development of the economy at current prices

\begin{tabular}{|l|c|c|c|c|c|c|}
\hline Index & 2011 & 2012 & 2013 & 2014 & 2015 & 2020 \\
\hline Added value, in trillion rubles & 8,4 & 9,3 & 10,3 & 11,4 & 12,6 & 19,6 \\
\hline Sector's contribution to GDP, $\%$ & $20,3 \%$ & $20,4 \%$ & $20,5 \%$ & $20,4 \%$ & $20,2 \%$ & $19,3 \%$ \\
\hline Total turnover, in trillion rubles & 56,1 & 62,1 & 68,9 & 76,2 & 84,2 & 132,7 \\
\hline Retail sales, in trillion rubles & 18,1 & 20,2 & 22,7 & 25,3 & 28,1 & 45,7 \\
\hline Volume index of retail trade turnover,\% by 2009 & $111 \%$ & $116 \%$ & $124 \%$ & $132 \%$ & $140 \%$ & $191 \%$ \\
\hline The retail trade turnover per capita, in thousand rubles & 127 & 142 & 159 & 176 & 196 & 314 \\
\hline Wholesale trade, in trillion rubles & 38,0 & 41,9 & 46,2 & 50,9 & 56,1 & 86,9 \\
\hline Employment, in million people & 12,9 & 12,9 & 12,9 & 12,9 & 12,8 & 13,5 \\
\hline Wages, in rubles a month & 17,8 & 19,6 & 21,7 & 24,2 & 27,6 & 47,7 \\
\hline Tax payments, in billion rubles & 831 & 940 & 1066 & 1204 & 1358 & 2349 \\
\hline Investments in fixed assets, in billion rubles & 408 & 481 & 570 & 672 & 800 & 1360 \\
\hline Performance of retail in thousand rubles per an employee & 1829 & 2073 & 2349 & 2667 & 3081 & 5206 \\
\hline The size of modern food retail space, in million square meters & 12,0 & 13,5 & 15,3 & 17,3 & 19,9 & 40,8 \\
\hline
\end{tabular}




\begin{tabular}{|c|c|c|c|c|c|c|}
\hline Index & 2011 & 2012 & 2013 & 2014 & 2015 & 2020 \\
\hline Provision with modern food retail space for 1000 people, in square meters & 84 & 95 & 107 & 121 & 139 & 281 \\
\hline The share of modern retail formats, $\%$ & $35 \%$ & $39 \%$ & $44 \%$ & $48 \%$ & $55 \%$ & $70 \%$ \\
\hline Networks share in retail, $\%$ & $27 \%$ & $31 \%$ & $35 \%$ & $40 \%$ & $45 \%$ & $65 \%$ \\
\hline The share of small enterprises of the total number of trading enterprises, $\%$ & $52 \%$ & $48 \%$ & $44 \%$ & $40 \%$ & $35 \%$ & $22 \%$ \\
\hline The share of retail trade turnover for a small business, $\%$ & $65 \%$ & $61 \%$ & $56 \%$ & $52 \%$ & $45 \%$ & $30 \%$ \\
\hline
\end{tabular}

Share of the trade network, in general, in its turnover will reach $35-45 \%$ in 2015 and $55-65 \%$ by 2020 compared to $20 \%$ in 2008. Increase of the share of trade network, of modern trade formats in retail turnover will implement a multiplier effect on tax deductions, comprising a substantial increase transparency in the sector. In the aggregate, the Russian economy expects a significant growth of tax payments. Thus, the total contribution of internal trade in the outer gross domestic product by 2015 will be about $21 \%$ and $19 \%$ by 2020 .

\section{References}

National economy in the RSFSR in 1990. Statistical Yearbook / State Statistical Committee of the RSFSR. - M.: Republican Information and Publishing Center, 1991. - 592 pages.

The Russian economy in 2004. Trends and Prospects. (26 Issue). Editor - Yegor Gaidar. - IEPP, 2005. - 684 pages.

Comprehensive information and analytical report "Socio-economic situation of the Republic of Tatarstan", January-December, Territorial Body of the Federal State Statistics Service of the Republic of Tatarstan.

Socio-economic situation of the Republic of Tatarstan / Territorial Body of Federal State Statistics Service of the Republic of Tatarstan. Kazan: № II - 2010 (January-February).

Socio-economic indicators of poverty in 2007-2010. / / Federal State Statistics Service (Rosstat). - M.: 2011. - 108 pages

Transcript of the joint meeting of the Ministry of Economic Development and the Ministry of Finance based on performance in 2010 and tasks for 2011, April 25, 2011. The official website of the Ministry of Finance of the Russian Federation

URL (http://www.minfin.ru/ru/press/transcripts/index.php?id4=12551).

L.B. Shabanova, V.N. Kouchnirenko "Economic and mathematical models as a tool to solve practical problems. Actual Problems of Economics and Law" 1 (25), March 2013. 
